\title{
Rare Variant of Bartter Syndrome with Sensorineural Deafness
}

\author{
Kumar $\mathbf{R}^{1}$, Kumar $\mathbf{P}^{2}$, Kumar $\mathbf{M}^{3}$
}

\begin{abstract}
Bartter syndrome is an inherited renal tubular disorder characterized by hypokalemia, hypochloremic metabolic alkalosis, hyperreninemia, hyper-prostaglandinism, normal blood pressure, with increased urinary loss of sodium, chloride, potassium, calcium and prostaglandins. There are five known type of Bartter syndrome, out of which type 4 and 5 are very rare. We are presenting here a case of Bartter syndrome with sensorineural hearing loss.
\end{abstract}

Key words: Metabolic Alkalosis, Hypokalemia, Bartter Syndrome, Sensorineural Hearing Loss.

\section{Introduction}

$B^{a}$ artter syndrome is a rare inherited defect in the thick ascending limb of the loop of Henle ${ }^{1}$. It is characterized by hypokalemia, metabolic alkalosis and normal to low blood pressure. Bartter syndrome can be divided into different subtypes on the basis of gene involved viz type 1- neonatal Bartter's syndrome, type 2 - neonatal Bartter's syndrome, type 3 - classic Bartter's syndrome, type 4 Bartter's syndrome with sensorineural deafness, type 5 - Bartter's syndrome associated with autosomal dominant hypocalcemia 2 A closely associated disorder, Gitelman's syndrome is a primary renal tubular hypokalemic metabolic alkalosis with hypocalciuria and magnesium deficiency ${ }^{3}$ and can be easily distinguished from Bartter's syndrome on the basis of urinary calcium levels ${ }^{4}$.

\section{The Case}

A 2 years old male was admitted to our hospital with complaints of vomiting, increased thirst and urination for 2 days. Parents also complained about delayed speech and the child was not able to speak even monosyllabous words. No other family member had similar illness and there was no history of parental consanguinity.

On examination, the child was of average built with normal motor milestones but defective language development as only cooing sounds were present. The child was not responding to sound. Blood pressure was $76 / 60 \mathrm{~mm} \mathrm{Hg}$ and pulse rate was 136 per minute. Dehydration was present. There was hypothermia but sensorium was normal. Systemic examination was within normal limit.
'Dr. Rajesh Kumar, MBBS, MD, Associate Professor. ${ }^{2}$ Dr. Pankaj Kumar, MBBS, MD, Assistant Professor. ${ }^{3}$ Dr. Manoj Kumar MBBS, MD, Assistant Professor. All from the Department of Paediatrics,SN Medical College, Agra, UP, India.

Address for correspondence:

Dr. Pankaj Kumar

E-mail: drpankaj_peds@hotmail.com

\section{How to cite}

Kumar R, Kumar P, Kumar M. Rare Variant of Bartter Syndrome with Sensorineural Deafness. J Nepal Paediatr Soc 2015;35(3):293-294.

doi: http://dx.doi.org/10.3126/jnps.v35i3.13076

This work is licensed under a Creative Commons Attribution 3.0 License.

\section{(c) (i)}

Laboratory investigations showed serum potassium $1.2 \mathrm{mEq} / \mathrm{L}$ ( 3.5-5 $\mathrm{mEq} / \mathrm{L})$, serum sodium-140 mEq/L (136-145 mEq/L), serum chloride- $58 \mathrm{mEq} / \mathrm{L}$ (96-106 $\mathrm{mEq} / \mathrm{L})$, serum bicarbonate $30 \mathrm{mEq} / \mathrm{L}(24-28)$, serum magnesium- $1.6 \mathrm{mg} / \mathrm{dl}$ (1.8-2.4 mg/dl), serum urea- $18.4 \mathrm{mg} / \mathrm{dl}$, serum creatinine$0.03 \mathrm{mg} / \mathrm{dl}$, blood pH-7.55 (7.35-7.45). The urine calcium was $8 \mathrm{mmols} / 24$ hour (2.5-7.5 $\mathrm{mmols})$, urine potassium was $186 \mathrm{mmols} / 24$ hour (25-150 mmols), urine chloride 302 mmols/24 hour (110-250 mmols), urine magnesium $10.7 \mathrm{mg} / 24$ hour (1.2-29.2 mg). Urine specific gravity and urine osmolality were normal. Serum aldosteron level was $462.02 \mathrm{ng} / \mathrm{I}(25-315 \mathrm{ng} / \mathrm{l})$.

On audiometric assessment $120 \mathrm{db}$ tones of various frequencies were given by head phone which did not elicit any 
response including eye blink or head turning suggesting $\mathrm{B} / \mathrm{L}$ severe to profound hearing loss.

Patient was treated with indomethacin, oral magnesium and potassium supplementation. Patient symptoms improved and discharged and referred to higher center for audiological rehabilitation.

\section{Discussion}

Bartter's syndrome is uncommon inherited abnormalities of ion channels in the thick ascending limb of the loop of Henle. It is characterized by hypercalciuria and nephrocalcinosis, and may be associated with maternal polyhydramnios, premature birth and low birth weight, and early onset of symptoms, including vomiting, Polydipsia, dehydration with hypotension, muscle weakness, paresthesias, and developmental delay ${ }^{5}$.

We report here a case of two year old boy with Bartter syndrome with bilateral sensorineural deafness. More than hundred cases of Bartter syndrome were identified. To our best knowledge this is the third case of Bartter syndrome with bilateral sensorineural deafness from the Indian community ${ }^{6}$.The infantile BS with sensorineural deafness, or type IV BS, is linked to autosomal recessive mutations in the BSND gene, located on chromosome 1p31 and coding Barttin protein ${ }^{7,8}$. Barttin protein is an essential subunit of the $\mathrm{ClC}-\mathrm{Ka}$ and $\mathrm{ClC}-\mathrm{Kb}$ chloride channels and is expressed in tubular segments spanning from the thick ascending limb to cortical collecting ducts in the kidney, whereas in the inner ear, it is expressed in potassium-secreting epithelial cells ${ }^{7}$. The underlying mechanisms of the saltlosing renal tubular disorder and of the related deafness have been a matter of interest for pediatricians, general practitioners, nephrologists, and otolaryngologists. In regard to hearing loss, the latest studies showed that sensorineural hearing loss in infantile BS is caused by the loss of outer hair cells and by a decrease in the mechanoelectrical transduction current of inner hair cells due to a drop in the endocochlear potential ${ }^{9}$.

Fluid and electrolytes should be postnatally replaced according to the extent of the loss. Indomethacin should be started in a low dose $(0.2$ $\mathrm{mg} / \mathrm{kg} /$ day). Close monitoring of serum creatinine, urinary prostaglandin, and serum indomethacin levels is mandatory to detect drug toxicity and response to therapy. The dose of indomethacin can then be titrated to achieve an adequate response. The indomethacin therapy has shown to decrease polyuria, renal saltwasting, hyperprostaglandinuria, hypercalciuria, and nephrocalcinosis ${ }^{10}$.

\section{Conclusion}

Metabolic syndromes should be suspected in any child presenting with vomiting, polydypsia, polyurea, dehydration and developmental delay. Audiological assessment should be done in all the cases of Bartter syndrome. Early intervention and timely audiological rehabilitation can improve quality of life in such children.

\section{References}

1. Bartter FC, Pronove P, Gill JR. Hyperplasia ofjuxtaglomerular complex with hyperaldosteronism and hypokalemic alkalosis. Am J Med 1962; 33: 811-28.

2. Naesens $M$, Steels $P$, Verberckmoes $R$, Vanrenterghem $Y$, Kuypers D. Bartter's and Gitelman's syndromes: from gene to clinic. Nephron Physiol 2004;96(3):65-78.

3. Bettinelli A, Bianchett MG, Girardin E, Caringella A, Cecconi M, Appiani AC, et al. Use of calcium excretion values to distinguish two forms of primary renal tubular hypokalemic alkalosis: Bartter's and Gitelman's syndrome. J Pediatr 1992;120:38-43.

4. Giteman HJ. Hypokalemia, hypomagnesemia and alkalosis: Arose is a rose- or is it? J Pediatr 1992;120:79-80.

5. Simon DB, Karet FE, Hamdan JM, Pietro AD, Sanjad SA, Lifton RP. Bartter's syndrome, hypokalaemic alkalosis with hypercalciuria, is caused by mutations in the Na-K-2Cl cotransporter NKCC2. Nat Genet 1996;13:183-88.

6. H. Swamy Dinesh et al. Pediat Therapeut 2012;2:6.

7. Zaffanello M, Taranta A, Palma A, Bettinelli A, Marseglia GL, Emma F. Type IV Bartter syndrome: report of two new cases. Pediatr Nephrol 2006;21(6):766-70.

8. Vollmer $\mathrm{M}$, Jeck $\mathrm{N}$, Lemmink $\mathrm{HH}$, et al. Antenatal Bartter syndrome with sensorineural deafness: refinement of the locus on chromosome 1 p31. Nephrol Dial Transplant 2000;15:970-74

9. Rickheit G, Maier H, Strenzke N, et al. Endocochlear potential depends on $\mathrm{Cl}$ channels: mechanism underlying deafness in Bartter syndrome IV. EMBOJ 2008;27:2907-917.

10. R. P. Bhamkar and A. Gajendragadkar Indian J Nephrol 2009;19(1):23-26. 